\title{
Effects of coating breeding eggs with different materials on quality of stored eggs and hatching results
}

\author{
M.A. Dorosti ${ }^{1}$, A. Shaddel Teli ${ }^{1 *}$ and M. Salmanzadeh ${ }^{2}$
}

\author{
${ }^{1}$ Departments of Animal Science, Shabestar branch, Islamic Azad University, 53815-159 Shabestar, ${ }^{2}$ Young \\ Researchers and Elite Club, Khoy branch, Islamic Azad University, 53815-159, Khoy, Iran \\ *corresponding author: Email-Shaddel_a@yahoo.com, Tel: +9842425311, Fax: +9842424927
}

Journal of Livestock Science (ISSN online 2277-6214) 10: 1-5

Received on 10/9/2018; Accepted on 1 /1/2019

doi. 10.33259/JLivestSci.2019.1-5

\begin{abstract}
The experiment was conducted to investigate the effects of coating breading eggs with different materials on the quality of stored eggs and hatching results. 400 fertile eggs were divided in a completely randomized design into five treatments, four replicates and each replicates contain 20 eggs. Experimental groups were following: 1) control (without coating egg), 2) coating egg with 50\% solution of honey, 3) coating egg with $50 \%$ solution of aqueous extract of propolis, 4) coating egg with $3 \%$ solution of gelatin, 5) coating egg with $50 \%$ solution of sugar. After testing, eggs stored for two weeks and then were transferred to the hatchery. In the end of the storage, egg quality traits (egg weight, sell weight, yolk weight, albumen weight, Haugh unit and albumen $\mathrm{pH}$ ) and at the end of the incubation period, characteristics hatchability (hatchability, weight and length of newly hatched chicks) were assessed. The results showed, coating the eggs with different materials were improved egg weight, yolk weight, albumen weight, Haugh unit and albumen $\mathrm{pH}(\mathrm{p}<0.05)$, whereas hadn't any significant effect on shell weight. Also, coating of eggs with mentioned materials had significantly reduced hatchability percentage than to control group (without coating egg) $(\mathrm{p}<0.05)$. But the effect of experimental groups hadn't any significant effect on the weight and length of the newly-hatched chicks. The results of this study showed, coating stored eggs with honey, propolis, gelatin and sugar can improve the quality traits of the broiler breeder eggs.
\end{abstract}

Key words: Broiler breeder egg; coating materials; egg quality traits; hatching traits 


\section{Introduction}

Two major important factors influencing egg quality are egg storage time and conditions (Williams, 1992). It is proven that some protection methods such as egg shell coating minimize detoriation in interior egg quality (Wong et al., 1996; Bhale et al., 2003). Previous studies have been conducted to assess egg shell coatings on increasing of interior egg quality, such as mineral oil, whey protein isolate, chitosan, shellac, soy protein isolate, wheat gluten, corn zein, and casein (Meyer and Spencer, 1973; Heath, 1977; Wong et al., 1996; Caner, 2005a, b; Caner and Cansiz, 2008).

Haugh unit is at maximum and albumen $\mathrm{pH}$ is at minimum when eggs are laid and their values decrease with increasing storage time (Silversides and Villeneuve, 1994; Silversides and Scott, 2001; Tilki and Inal, 2004). Haugh unit is an empirical method that determines a relationship between the weight and height of the thick albumen (Haugh, 1937; Stadelman, 1995b). When eggs age, the thick albumen breaks down into thin albumen. This break down results in a decreased height of the thick albumen, which is the primary factor in the HU equation. A higher HU value (i.e., thick albumen height) indicates a higher quality egg. The $\mathrm{pH}$ increases during storage due to carbon dioxide loss through the porous shell (Powrie, 1973; Heath, 1977; French and Tullet, 1991; Wong et al., 1996; Tayar, 2005). In general, eggshells are breathable material; therefore they allow moisture and carbon dioxide to permeate through the shell (Wong et al., 1996). The permeation may cause physical and chemical changes in albumen and yolk and also weight loss.

Since the egg shell coating limits water losses and gas diffusion through pores, it should be useful to coat breeding eggs shell with different materials during storage. Therefore, the objectives of this study were to investigate the influence coating stored eggs with honey, propolis, gelatin and sugar on the interior quality of eggs.

\section{Material and method}

Hatching eggs of approximately similar weights $(67 \pm 1 \mathrm{~g})$ were obtained from broiler breeder strain (Ross $308)$ at 41 weeks of age. Food-grade coatings used in this study were honey, propolis, gelatin, sugar and uncoated (control). 400 fertile eggs were divided in a completely randomized design into five treatments, four replicates and each replicates contain 20 eggs. Experimental groups were following: 1) control (without coating egg), 2) coating egg with $50 \%$ solution of honey, 3) coating egg with solution of aqueous extract of propolis, 4) coating egg with $3 \%$ solution of gelatin, 5) coating egg with $50 \%$ solution of sugar. After testing, eggs stored for two weeks and then were transferred to the hatchery. Fertile eggs were incubated at $37.7 \circ \mathrm{C}$ and $64 \% \mathrm{RH}$.

In the end of the storage, egg quality traits (egg weight, sell weight, yolk weight, albumen weight, Haugh unit and albumen $\mathrm{pH}$ ) and at the end of the incubation period, characteristics hatchability (hatchability, weight and length of newly hatched chicks) were assessed.

Coating Applications

Honey and propolis was collected from honey bees in Khoy and extracted according to the method suggested by Krell (1996). a $50 \%$ propolis were prepared by mixing $1600 \mathrm{ml} 70 \%$ ethanol and $400 \mathrm{~g}$ of propolis. Solutions were kept in a container, sealed the top and shaken twice daily for one week. Each solution was filtered separately and was kept in a clean, dark bottle at $4^{\circ} \mathrm{C}$ until use. Four different food-grade coatings were applied to eggs: honey, propolis, gelatin, sugar. Propolis was melted at $60^{\circ} \mathrm{C}$ and eggs were dipped using a pair of tongs that made contact with the eggs with 2 small holes on the side of the eggs. When the tongs were removed from the dried eggs, the holes were filled with paraffin wax. Coating of the honey, gelatin and sugar eggs all used the same process. The pointed end of the egg was dipped into the respective coating and then placed on a small stand pointed side down. The food-grade coating was then poured over the egg until it visibly covered the surface. Care was taken to ensure that each egg had a uniform coating with no visible defects. The eggs were air-dried at ambient conditions for approximately $30 \mathrm{~min}$ and were then moved by hand into cartons for the rest of the storage (Biladeau and Keener, 2009).

Measuring the weight of egg, albumen, yolk and shell

Sensitivity was used for weighing the albumen, yolk and shell weights of the eggs. After the weighing process, the eggs were broken and accurately divided into three components: shell, yolk, and albumen. The yolk and albumen were weighed immediately after breaking; the shell was dried at the room temperature and weighed after water evaporation from the solid substance (Narushin et al. 2001).

HU Measurements

Haugh units were measured on 5 eggs using an Egg Multi Tester (Robotmation Co., Tokyo, Japan). This machine measures an average of the egg albumen height using ultrasound. 


\section{pH Measurements}

Five of the 5 eggs measured for $\mathrm{HU}$ were also selected for $\mathrm{pH}$ analysis. The albumen and yolk were separated and albumen $\mathrm{pH}$ measured using a model 220 Denver Instrument $\mathrm{pH}$ meter (Denver Instrument, Denver, $\mathrm{CO}$ ). Upon hatching, the number of hatchlings was determined to calculate the hatchability of fertile eggs. The weight of newly hatched chickens was determined by weighing all chickens hatched one by one.

Analyses of variance were performed using the GLM procedure of SAS Institute Inc. (2005) as a completely randomized design. Results are presented as mean \pm SEM. The significantly different treatment means were investigated using Duncan's new multiple rang test. Differences were considered significant when $\mathrm{p}<0=05$.

\section{Results}

The effects of coating breeding eggs with different materials on weight of egg, albumen, yolk and shell are presented in Table 1. The weight of egg, albumen and yolk were significantly increased in eggs treated by honey, propolis, gelatin and sugar compared to the control group. By contrast, shell weight was not significantly altered in treated eggs. Haugh unit and albumen $\mathrm{pH}$ markedly improved in eggs treated with honey, propolis, gelatin and sugar compared to the control group (Table 2). As seen in Tables 3 the coating breeding eggs with different materials reduced the hatchability compared with the control group. But, the mean body weights and length of newly hatched chickens coated by honey, propolis, gelatin and sugar were not significantly altered.

Table 1. Effects of coating breeding eggs with different materials on weight of egg, albumen, yolk and shell

\begin{tabular}{|l|c|c|c|c|}
\hline Groups & Egg $(\mathbf{g})$ & Albumen $(\mathbf{g})$ & Yolk $(\mathbf{g})$ & hhell $(\mathbf{g})$ \\
\hline control & $97.05 \mathrm{c}$ & $58.82 \mathrm{~b}$ & $31.68 \mathrm{~d}$ & 8.54 \\
\hline honey & $98.98 \mathrm{a}$ & $57.86 \mathrm{a}$ & $32.58 \mathrm{a}$ & 8.54 \\
\hline propolis & $98.37 \mathrm{~b}$ & $57.69 \mathrm{a}$ & $32.14 \mathrm{bc}$ & 8.52 \\
\hline gelatin & $98.08 \mathrm{~b}$ & $57.61 \mathrm{a}$ & $32.00 \mathrm{c}$ & 8.47 \\
\hline sugar & $98.57 \mathrm{ab}$ & $57.81 \mathrm{a}$ & $32.32 \mathrm{~b}$ & 8.42 \\
\hline SEM & 0.0001 & 0.0001 & 0.0001 & 0.4787 \\
\hline P-Value & 0.179 & 0.121 & 0.084 & 0.052 \\
\hline
\end{tabular}

Table 2. Effects of coating breeding eggs with different materials on Haugh unit and Albumen $\mathrm{pH}$

\begin{tabular}{|l|c|c|}
\hline Groups & Haugh unit & Albumen pH \\
\hline control & $73.31 \mathrm{c}$ & $9.19 \mathrm{a}$ \\
\hline honey & $74.64 \mathrm{a}$ & $8.85 \mathrm{~b}$ \\
\hline propolis & $74.36 \mathrm{ab}$ & $8.63 \mathrm{~b}$ \\
\hline gelatin & $74.42 \mathrm{a}$ & $8.71 \mathrm{~b}$ \\
\hline sugar & $73.91 \mathrm{~b}$ & $8.79 \mathrm{~b}$ \\
\hline SEM & 0.0001 & 0.0004 \\
\hline P-Value & 0.148 & 0.068 \\
\hline
\end{tabular}

${ }^{a-e}$ Averages in a column with different superscript letters are significantly different.

Table 3. Effects of coating breeding eggs with different materials on weight and hatchability in newlyhatched chickens

\begin{tabular}{|l|c|c|c|}
\hline Groups & Hatchability $\mathbf{( \% )}$ & Weight $(\mathbf{g})$ & Length $\mathbf{( C m )}$ \\
\hline control & $84.02 \mathrm{a}$ & 43.41 & 19.70 \\
\hline honey & $74.30 \mathrm{~b}$ & 43.61 & 19.40 \\
\hline propolis & $69.44 \mathrm{~b}$ & 43.46 & 20.40 \\
\hline gelatin & $72.22 \mathrm{~b}$ & 43.52 & 20.60 \\
\hline sugar & $75.00 \mathrm{~b}$ & 43.59 & 20.30 \\
\hline SEM & 0.0056 & 0.0647 & 0.1911 \\
\hline P-Value & 2.310 & 0.051 & 0.382 \\
\hline
\end{tabular}

${ }^{\mathrm{a}-\mathrm{e}}$ Averages in a column with different superscript letters are significantly different. 


\section{Discussion}

Based on the results of the present study, coating breeding eggs with different materials can be seen as an effective tool to improve interior egg quality. The results presented agree with the study reported by Wong et al. (1996) and Bhale et al. (2003) demonstrating that some protection methods such as egg shell coating minimize deterioration in interior egg quality. The edible films, which are not detrimental to human health, have a barrier property against oxygen, carbon dioxide and humidity movement from eggs (Caner et al., 1998; Krochta and Dcmulder, 1997). Some conservation methods including oil coating (Hisil and Otles, 1997), dipping in low tem-perature, freezing, high temperature and drying (Tayar, 2005) and also the coating of egg shell with chitosan, whey protein and shellac (Caner 2005b) are used for protection of interior egg quality.

Results of the present study showed that the weight of egg, albumen and yolk were significantly increased in eggs treated by honey, propolis, gelatin and sugar compared to the control group. in agreement, Biladeau and Keener (2009) reported that the linear slope from highest to lowest is $0.28 \mathrm{~g} / \mathrm{wk}$ for control, $0.24 \mathrm{~g} / \mathrm{wk}$ for SPIcoated eggs, $0.23 \mathrm{~g} / \mathrm{wk}$ for WPI-coated eggs, $0.03 \mathrm{~g} / \mathrm{wk}$ for oil-coated eggs, and $0.002 \mathrm{~g} / \mathrm{wk}$ for wax-coated eggs. Coated eggs had a lower sample variance than the control, suggesting that a food-grade coating will reduce water loss in more porous eggs. Also, Biladeau and Keener (2009) showed that the total weight (water) loss during $12 \mathrm{wk}$ of refrigerated storage for control, SPI-, WPI-, oil-, and wax-coated eggs was 3.4, 2.9, 2.7, 0.35, and $0.03 \mathrm{~g}$, respectively. These values are comparable to previous research. Caner (2005a) found the weight loss was $6.8 \%$ for control, $4.3 \%$ for WPI-coated eggs, $4.2 \%$ for chitosan-coated eggs, and $0.7 \%$ for shellac-coated eggs over a 4 -wk study at room temperature.

The determination of albumen $\mathrm{pH}$ in fresh egg is more important than determination of albumen height. In general, the $\mathrm{pH}$ of the albumen does not differ between genetic strains, but increases with storage time (Silversides and Scott, 2001). An increase in albumen pH causes a decrease in egg quality (Scott and Silversides, 2000). Previous researchers showed the starting value of albumen $\mathrm{pH}$ between of 7.6-7.9 (Powrie, 1973; French and Tullet, 1991; Silversides and Scott, 2001; Senkoylu, 2001). The current study indicates that increasing storage time caused an increase in albumen $\mathrm{pH}$ of the egg $(\mathrm{p}<0.05)$ (Table 2). Eggs coated with honey, propolis, gelatin and sugar exhibited lower $\mathrm{pH}(\mathrm{p}<0.05)$ than eggs control group. According to these results, it may be assumed that eggshell coating decreased $\mathrm{CO} 2$ release through the shell by acting as a barrier for $\mathrm{CO} 2$. In general, coatings may force some gasses to diffuse less rapidly than others through the shell. The observed values supported previous work conducted by Caner, (2005b) who found similar $\mathrm{pH}$ values when coating eggs with chitosan (8.83) and shellac (8.82). In general, the observed increase in albumen $\mathrm{pH}$ supports the conclusions of previous studies (French and Tullet, 1991; Wong et al., 1996; Tayar, 2005) that the pH increases with CO2 loss via egg shell pores during storage time. In the study of Stadelman (1995a), it was reported that the increase in albumen $\mathrm{pH}$ over time is related to the loss of CO2. As albumen $\mathrm{pH}$ increases, the bicarbonate buffering system equilibrium shifts (Heath, 1977). For coated eggs, this buffering system may not shift as quickly.

In present study, the coating breeding eggs with different materials reduced the hatchability compared with the control group. According to the past studies and our present observations, it seems that coating breeding eggs with different materials can be harmful for the internal environment susceptibility and may have negative effects on hatching.

\section{References}

1) Bhale S, No HK, Prinyawiwatkul W, Faar AJ, Nadarajah K, Meyers SP, 2003. Chitosan cooating improves shell life of eggs. Journal of Food Science 68:2378-2383.

2) Biladeau AM, Keener KM, 2009. The effects of edible coatings on chicken egg quality under refrigerated storage. Poultry Science 88:1266-1274.

3) Caner C, Cansiz O, 2008. Chitosan coating minimizes eggshell breakage and improves egg quality. Journal of Science Food Agriculture 88:56-61.

4) Caner C, 2005a. The effect of edible eggshell coatings on egg quality and consumer perception. Journal of Science Food Agriculture 85:1897-1902.

5) Caner C, 2005b. Whey protein isolate coating and concentration effects on egg shelf-life. Journal of Science Food Agriculture 85:2143-2148.

6) Caner C, Ergano PJV, Iles JLW, 1998: Chitosan film mechanical and permeation properties as affected by acid, plasticizer, and storage. Journal of Food Science 63:1049-1053. 
7) French NA, Tullet SG, 1991. Variation in the eggs of poultry species. Avian Incubation 22nd Poultry Science Symposium, Butterworth-Heinemann Ltd. 59-77.

8) Haugh RR, 1937. The Haugh unit for measuring egg quality. US Egg Poultry Magazine 43:522-573.

9) Heath JL, 1977. Chemical and related osmotic changes in egg albumen during storage. Poultry Science 56:822828.

10) Hisil Y, Tles SO, 1997. Changes of vitamin B-1 con-centrations during storage of hen eggs. Food Science Technology 30:320-323.

11) Krell R, 1996. Value-added products from beekeeping. FAO Agricultural Services Bulletin No: 124, Food and Agriculture Organization of the United Nations Rome, Italy.

12) Krochta JM, Cmulder JCD, 1997. Edible and biode-gradable polymer films: Challenges and opportunities. Food Technology 51:61-74.

13) Meyer R, Spencer JV, 1973. The effect of various coatings on shell strength and egg quality. Poultry Science 52:703-711.

14) Narushin VG, Yakupoglu C, Dvorska J, 2001. Morphological composition of quail eggs. IX European symposium on the quality of eggs and egg products. Kusadasi, Turkey, 387-392.

15) Powrie WD, 1973. Egg Science and Technology. In William J. Stadelman (ed), and Owen J. Cotterill (ed), The AVI PUBLISHING COMPANY INC., Westport, Connecticut.

16) Scott T, Silversides FG, 2000. The effect of storage and strain of hen on egg quality. Poultry Science 79:17251729.

17) Senkoylu N, 2001. Modern Tavuk Uretimi. Trakya Univ. Ziraat Fak. 3. Baski, Tekirdağ, Turkiye. pp 276-290.

18) Silversides FG Villeneuve P, 1994. Is the Haugh unit correction for egg weight valid for eggs stored at room temperature. Poultry Science. 94:50-55.

19) Silversides FG, Scott TA, 2001. Effect of storage and layer age on quality of eggs from two different lines of hens. Poultry Science 80:1240-1245.

20) Stadelman WJ, 1995a. The preservation of quality in shell eggs. Pages 67-79 in Egg Science and Technology. 4th ed. W. J. Stadelman and O. J. Cotterill, ed. Food Products Press, New York, NY.

21) Stadelman WJ, 1995b. Quality identification of shell eggs. Pages 39-66 in Egg Science and Technology. 4th ed. W. J. Stadelman and O. J. Cotterill, ed. Food Products Press, New York, NY.

22) Tilki M, Inal S, 2004. Quality traits of goose eggs. 1. Effects of goose age and storage time of eggs. Arch. Für Geflügelkun 68: 182-186.

23) Williams KC, 1992. Some factors affecting albumen quality with particular reference to Haugh unit score. World's Poultry Science Journal 48:5-16.

24) Wong YC, Herald TJ, Hachmeister KA, 1996. Evaluation of mechanical and barrier properties of protein coatings on shell eggs. Poultry Science 75:417-422. 